CHAUCER AND HIS ENGLISH CONTEMPORARIES 
Also by W. A. Davenport

CHAUCER: COMPLAINT AND NARRATIVE FIFTEENTH-CENTURY ENGLISH DRAMA THE ART OF THE GAWAIN-POET 


\title{
Chaucer and His English Contemporaries
}

Prologue and Tale in The Canterbury Tales

\author{
W. A. Davenport
}


All rights reserved. No reproduction, copy or transmission of this publication may be made without written permission.

No paragraph of this publication may be reproduced, copied or transmitted save with written permission or in accordance with the provisions of the Copyright, Designs and Patents Act 1988, or under the terms of any licence permitting limited copying issued by the Copyright Licensing Agency, 90 Tottenham Court Road, London WIP 9HE.

Any person who does any unauthorised act in relation to this publication may be liable to criminal prosecution and civil claims for damages.

The author has asserted his rights to be identified as the author of this work in accordance with the Copyright, Designs and Patents Act 1988.

First published 1998 by

MACMILLAN PRESS LTD

Houndmills, Basingstoke, Hampshire RG21 6XS

and London

Companies and representatives throughout the world

ISBN 978-0-333-60132-7

DOI 10.1007/978-1-349-26738-5

A catalogue record for this book is available from the British Library.

This book is printed on paper suitable for recycling and made from fully managed and sustained forest sources.

$\begin{array}{llllllllll}10 & 9 & 8 & 7 & 6 & 5 & 4 & 3 & 2 & 1\end{array}$

$\begin{array}{llllllllll}07 & 06 & 05 & 04 & 03 & 02 & 01 & 00 & 99 & 98\end{array}$

Editing and origination by Aardvark Editorial, Mendham, Suffolk

Published in the United States of America 1998 by

ST. MARTIN'S PRESS, INC.,

Scholarly and Reference Division,

175 Fifth Avenue, New York, N.Y. 10010

ISBN 978-0-312-21438-8 cloth

ISBN 978-0-312-21439-5 paperback 


\section{Contents}

Preface

vii

Abbreviations

ix

1 Introduction: Prologue and Tale 1

2 Prologues 9

I Medieval Prologues 9

II Gower, Langland and Chaucer's General Prologue 21

III Prologues in The Canterbury Tales 35

3 Tales $\quad \mathbf{5 0}$

I Ideas of Narrative $\quad 50$

II Tales and Preachers $\quad 58$

III Fabliau, Confession, Satire $\quad 72$

4 Romances $\quad 92$

I Romance as a Medieval Genre 92

II The Case of Thomas Chester 95

III English Romances 107

IV Chaucer and Romance 116

5 Chaucer, Gower and the Gawain-Poet 133

I Emaré and the Tale of Constance 133

II The Tale of Florent and The Wife of Bath's Tale 146

III Chaucer and Sir Gawain and the Green Knight 159

6 Forms of Narrative 167

I Frameworks 167

$\begin{array}{ll}\text { II Well-made Narrative } & 179\end{array}$

III Wayward Narrative 188

7 The Good Way 208

$\begin{array}{ll}\text { Notes } & 218\end{array}$

Bibliography 229

Index 238 


\section{Preface}

Long ago I studied Chaucer's General Prologue as a set text for the Oxford School Certificate (replaced by the old O levels soon after), and a very odd piece of poetry it seemed to me at the age of fourteen, not much like 'The Pied Piper of Hamelin' or 'The Jackdaw of Rheims', which were the sort of thing I had learnt to expect narrative poetry to be, nor fitting into any other category I knew. I am more familiar with it now and with medieval poetry in general than I was then, but it still seems an odd work to me, partly because I find it difficult not to read it as I first knew it, that is as a self-contained poem, rather than as a preliminary to something else. Is the General Prologue actually much like a prologue? What is a prologue anyway?

From such questions this book began and it was natural to move from prologue to tale, the main component of The Canterbury Tales, and to realise that tale too was a supposedly obvious literary notion, where Chaucer's use of the form was far from simple. Trying to answer questions about what Chaucer thought a prologue and a tale to be, I turned to contemporary English writing to see if other poets were producing works similar enough to Chaucer's to help explain his versions. And so the book developed into a discussion of The Canterbury Tales alongside other narrative works of the fourteenth century, the poems of Gower, Langland and the Gawain-Poet, the Middle English romances and alliterative poems. The resulting book is about The Canterbury Tales and some of the ways in which reading Chaucer in the company of the other writers of his time, particularly those writing in English, can help one to understand the literary ideas which he was exploring in his great compilation of tales and their prologues.

The reader will find discussion of all twenty-four of the tales somewhere in the book, though in some cases a brief one, but I have not attempted an exposition of each in turn: on the one hand I have thought of them in groups, according to genre, and so have looked at some aspects of Chaucer's didactic narratives and then of his fabliaux in Chapter 3, and at the romances in The Canterbury Tales in Chapter 4, with detailed commentary on the two longest stories Chaucer shares with Gower in Chapter 5; in Chapter 6, on the other hand, I have 
grouped them according to my judgement of how near to and how far from a conception of normal narrative patterns the various tales are.

In writing this book I have assumed that the reader is, to some degree, used to reading Chaucer and has a general knowledge of his works and other literature of Chaucer's period. Some glosses have been added to the quotations to remind readers of some fourteenth-century usages and to save looking up unusual words and expressions, and the spelling of medieval texts has been slightly modernised, though only to the extent of replacing obsolete letters by their modern equivalents.

A version of parts of Chapter 2 was delivered as a paper to the London Old and Middle English Research Seminar in 1993, and an earlier version of part of Chapter 6 was delivered as a paper to the Graduate Centre for Medieval Studies at the University of Reading in 1991; to the members of both groups I extend my thanks for their helpful comments at the time. Several of my colleagues, academic and administrative, at Royal Holloway, University of London have given help of various kinds and I am grateful to them, particularly to Joyce Bianconi for sorting out my word-processing problems. Hester, my wife, knows how grateful I am for her encouragement, for reading the drafts of each chapter, and for making sure that some of my commas are in the right places, but let me record it here. 


\section{Abbreviations}

Bennett and Gray MEL J.A.W. Bennett and D. Gray, Middle English Literature, Clarendon Press, Oxford, 1986

Burrow $R P$

J.A. Burrow, Ricardian Poetry: Chaucer, Gower, Langland and the Gawain-Poet, Routledge \& Kegan Paul, London, 1971

$C A$ Confessio Amantis [All quotations are from G.C. Macaulay (ed.), The Works of John Gower: English Works, 2 vols, Clarendon Press, Oxford, 1900-01.]

ChanR Chaucer Review

Cooper OGCT

Cooper Structure

$C T$

EC

EETS

Fellows et al.

Helen Cooper, Oxford Guides to Chaucer: The Canterbury Tales, Clarendon Press, Oxford, 1989

Helen Cooper, The Structure of The Canterbury Tales, Duckworth, London, 1983

The Canterbury Tales

Essays in Criticism

Early English Text Society

J. Fellows, R. Field, G. Rogers and J. Weiss (eds), Romance Reading on the Book: Essays on Medieval Narrative presented to Maldwyn Mills, University of Wales Press, Cardiff, 1996

Fisher $J G$

John H. Fisher, Jobn Gower, Moral Philosopher and Friend of Chaucer, Methuen, London, 1965

JEGP

Journal of English and Germanic Philology

Kean

P.M. Kean, Chaucer and the Making of English Poetry, 2 vols, 1972; shortened version, Routledge \& Kegan Paul, London, 1982

$M A e$

Medium Aevum

Meale Readings

Carol M. Meale (ed.), Readings in Medieval English Romance, D. S. Brewer, Cambridge, 1994 
$M L N$

$M L Q$

$M L R$

$M S$

NM

Pearsall $C T$

Pearsall $O E \mathcal{E} M E P$

PMLA

$P P l$

$P Q$

Riverside

$S A C$

TEC

YES
Modern Language Notes

Modern Language Quarterly

Modern Language Review

Mediaeval Studies

Neuphilologische Mitteilungen

Derek Pearsall, The Canterbury Tales, Allen \& Unwin, London, 1985

Derek Pearsall, Old English and Middle English Poetry, Routledge \& Kegan Paul, London, 1977

Publications of the Modern Language Association

Piers Plowman [All quotations are from the B-Text as in A.V.C. Schmidt (ed.), William Langland, The Vision of Piers Plowman, Dent, London, 1978.]

Philological Quarterly

L.D. Benson et al., The Riverside Chaucer, Oxford University Press, Oxford, 3rd edn, 1988 [All quotations from Chaucer are from this edition.]

Studies in the Age of Chancer

Troilus and Criseyde

Yearbook of English Studies 